\title{
Initiating Gender-Responsive Budgeting: Implementation of Earmarking Tax on Cigarette Tax Policy
}

\author{
Murwendah $^{1}$, Inayati ${ }^{2}$, Maisarah Putri Atsani ${ }^{3}$ \\ murwendah09@ui.ac.id ${ }^{1}$,inayati.si@ui.ac.id ${ }^{2}$, maisarahatsani@gmail.com ${ }^{3}$ \\ Department of Tax Administrative Science, Faculty of Administrative Science, Universitas \\ Indonesia ${ }^{1,2,3}$
}

\begin{abstract}
Studies focusing on the application of Gender-Responsive Budgeting in Indonesia are limited. Taxes as the largest source of state revenues shall ideally consider the issue of gender equality, in fact the policy tends to overlook gender issue, for instance income tax law only consider men as a head of family, instead of women. Earmarking tax can be used as an instrument to allocate state revenues for certain expenditures to achieve certain interests expected by the government. One of the earmarking tax policies in Indonesia is applied to cigarette tax that is imposed by provincial government. This study aims to analyze the earmarking tax on cigarette taxes in the perspective of GenderResponsive Budgeting. This research applied a qualitative approach through literature study and in-depth interviews to collect the data. The findings show that the implementation of earmarking tax on cigarette taxes has not paid attention to the aspect of Gender-Responsive Budgeting. Due to different interpretations between the stakeholders involved both at the central and regional government levels, the allocation of state revenues tends to be equated with other allocations without paying attention to the concept of earmarking tax. Furthermore, the state and regional financial management systems have not accommodated the earmarking tax concept. It is essential to build a framework of study regarding new policies on sensitive-gender tobacco control, particularly GenderResponsive Budgeting, specifically concerned with the allocation of tax revenues for empowering women.
\end{abstract}

Keywords: Tax Policy, Cigarette Tax, Earmarking Tax, Gender-Responsive Budgeting, West Java

\section{Introduction}

Nearly 10 percent of 1 billion smokers in the world live in ASEAN. Based on World Health Organization's (WHO) Global Health Observatory, smoking predominance among male adults increases from 28 percent (Singapore) to 76 percent (Indonesia) in 2015. By 2020, smoking predominance among ASEAN male adults is predicted to increase from 28 percent (Singapore) to 83 percent (Indonesia) [1]. In 2015, Indonesia and the Philippines were respectively ranked third and tenth among 10 countries with the largest smoking population in the world [1]. At global policy scale, WHO launches the MPOWER package to control cigarettes consumption, namely 1) Monitoring tobacco consumption and prevention policies; 2) Protecting people from tobacco smoke; 3 ) Offering help to quit consuming tobacco; 4) Warning the dangers of tobacco; 5) Enforcing bans on tobacco advertising, promotion and sponsorship; 
and 6) Raising taxes on tobacco [2]. Unfortunately, Indonesia decided not to ratify the MPOWER program. However, tax instruments (referring to point 6 of MPOWER program) are applied to control tobacco consumption in Indonesia. In relation to tobacco tax, the Ministry of Finance and the Ministry of Health developed regulation of the utilization of cigarette tax revenue to support health promotion [3]. Starting in January 2014, at least 50\% of the revenue collected from tobacco excise shall be allocated to health and law enforcement (earmarking tax) to be directly disbursed to the provincial level based on the number of population [4]. Earmarking tax is a certain revenue received by the government allocated specifically to fund certain public services [5]. The policy on cigarette taxes is regulated in Article 31 of Law No 28 of 2009 on Regional Taxes and Charges (hereinafter referred to as the PDRD Law) [4].

Particularly in Asia, gender is a frequently overlooked determinant of tobacco consumption control. In numerous social orders in the world, it is proven that hazardous practices (including tobacco consumption) are significantly carried out by men as the representation of masculinity $[6$, p. 25]. In Indonesia, it is found that infant, children, and women are affected negatively by cigarettes six time higher in terms of health and economy compared to men [7], [8]. In terms of tax issue, Indonesia tax law tends to disregard gender-sensitive policy in general. For instance, income tax law has not considered women as a head of family, instead of men in conducting their income tax liability. Although the law allows splitting income and single unit or income separation between men and women, the law has not reflected gender equality yet [9, p. 63].

Regarding the implementation of earmarking tax, it is interesting to observe it from a gender perspective. It is essential to observe whether the tax policy on cigarette in Indonesia pays attention to gender issues or not. Therefore, this study aims to analyze the implementation of earmarking tax policy on cigarette tax in a Gender-Responsive Budgeting (GRB) perspective in West Java. The Province of West Java was selected as the locus of the study considering that the province received the largest allocation of cigarette tax revenue in Indonesia in compliance with the Decree of the Director General of Fiscal Balance on the Proportion and Estimation of Cigarette Tax Revenue for Each Province in the 2016, 2017, and 2018 Fiscal Year [10]-[13].

\section{Theoretical Framework}

This study applied several concepts, such as policy implementation, earmarking tax, and regional tax, and GRB. Policy implementation is the actions of individuals or groups or governments to achieve goals based on a policy decision [14, p. 20]. Earmarking is certain revenues received by the government to specifically fund certain public services [15, p. 20]. Earmarking tax is grouped into two types, namely substantive earmarking and symbolic earmarking. Substantive earmarking is the income allocated to fund certain expenditures. On the other hand, symbolic earmarking is the income with no direct impact on the amount of expenditures and included in general fund [16]. Earmarking is an application of the benefit principle of taxation [5], [15]. Benefit taxation is a system of tax imposition for individuals based on the benefits they receive from public expenditures.

As part of regional taxes, cigarette tax is an example of earmarking tax policy. Regional taxes include several types of taxes: taxes collected by the regional government through the regulation of the regional government; taxes collected based on national regulation whose rates are determined by the regional government; taxes determined and/or collected by the regional government; and taxes collected and administered by the central government whose revenue are distributed to the regional government [17]. 
One of the points of view related to gender used in this study was GRB since it is relevant for everyone - women and men as well as young women and young men - and fundamental both for gender and monetary equity. It includes examining state revenue and expenditure budget and its consequences for gender, related standards and jobs, and gender relations. It is expected to guarantee that gender correspondence duties are taken into account [18], [19].

\section{Method}

This study is a baseline research of the umbrella research on evaluation of cigarette taxes in Indonesia. This study applied a qualitative approach. The data were collected by literature study and field study through in-depth interviews with relevant stakeholders, namely the Fiscal Policy Agency, the Directorate General of Financial Balance, the Directorate General of Regional Finance of the Ministry of Home Affairs, the Health Office of West Java Province, Regional Development Planning Agency of West Java Province, Regional Financial and Asset Management Agency (BPKAD) of West Java Province, and tax experts.

\section{Findings and Discussions}

In practice, the earmarking tax policy on cigarette taxes is deemed unable to control tobacco consumption since (1) smoking prevalence in Indonesia continues to increase even though the cigarette tax policy has been implemented, and (2) the allocation of cigarette tax revenue has not been fully utilized in accordance with the mandate of the PDRD Law, particularly in terms of gender sensitive policy. The findings of this study show that cigarette tax revenue has not been utilized for public health services, particularly in West Java Province. In referring to Law No. 17 of 2003 on State Finance and Regional Regulation of West Java Province No. 12 of 2008 on the Principles of Regional Financial Management, all regional revenues and expenditures shall be clearly allocated in a special account, namely Regional Revenue and Expenditure Budget. Thus, it shall be difficult to distinguish the revenue from cigarette taxes. It indicates a symbolic earmarking in which the revenue from the earmarking tax policy has no direct impact on the amount of expenditures and is included in general fund.

In this regard, the earmarking tax policy on cigarette taxes in West Java Province has not been specifically related to expenditure policies. The Ministry of Health as the central government is aware of this issue since the Health Office of West Java Province does not receive funds allocated from cigarette tax revenue. However, BPKAD states that $50 \%$ of cigarette tax revenue has been allocated to the Health Office of West Java Province, yet the funds are not utilized. The Ministry of Health contradicts this statement.

The Health Office of West Java Province has developed preventive smoking ban activities, yet these activities are considered contrary to the Regulation of the Ministry of Health No. 222 of 2017 on the Utilization, Monitoring, and Evaluation of Revenue Sharing of Excise Tobacco Products. In terms of administrative capacity, the Health Office does not understand the relevant regulations and policies. Eventually, the Health Office of West Java Province decides not to utilize the funds to avoid disagreement with Audit Board.

Observed from the data of smoking prevalence, smokers tend to be dominated by men. In addition, women and children tend to be passive smokers exposed to greater negative impact of smoking than active smokers [7]. Referring to the perspective of GRB, its activities are not 
merely 'budgeting for women', regardless of their administration specifically directed for the interests of women [18]. GRB also does not divide government expenditures for women and men by 50:50. Instead, GRB observes the budget from the perspective of gender to analyze how the budget shall fulfill the diverse needs of everybody, including women and men as well as young women and young men. GRB can also evaluate the needs of women and men as well as young women and young men based on other indicators.

Concerning to earmarking tax in tobacco tax, it is found that this policy has not considered the implementation of RGB. Even the stakeholders involved has not implemented well as the allocation is not utilized in accordance with the mandate of the PDRD Law. In the stage of policy formulation, this policy did not pay attention to gender issues since its main purpose is only to allocate revenues from cigarette taxes for specific expenses without differentiating gender-based expenditure needs. At the stage of formulation and implementation of policies, it is known that this policy does not consider the relation of the negative effects of smoking by active smokers to women and children as passive smokers. For instance, there is no program specifically designed to prevent passive smoking from children and women groups or programs that specifically focus on treatment for children and women due to passive smoking. In practice, the implementation of the earmarking tax on cigarette taxes coincides with the use of the revenue sharing fund of tobacco excise which also overlooking gender issues. In fact, the use of existing budget is only for public health services as well as disregarding the law enforcement aspect, such as related to control of illegal cigarettes.

Overall, most of tax policies in Indonesia has not been sensitive to gender issues currently. Even though the Ministry of Finance has sought the establishment of gender-based state financial policies as stipulated in the President's Instruction No. 9 of 2000 concerning Gender Mainstreaming in National Development. As a follow-up to the policy, the Ministry of Finance and the Ministry of Women's Empowerment and Child Protection issued the Regulation of the Ministry of Finance No. 119/PMK.02/2009 concerning Guidelines for Preparation and Review of the 2010's Ministry/ Institution Work Plan and Budget, and the Regulation of the Ministry of Finance No. 104/PMK.02/2010 concerning Guidelines for Preparation and Review of Ministries/ Institutions Work Plans and Budgets Year 2011, which require related ministries/ institutions to attach Gender Budget Statements and Terms of Reference in their budgeting statements [20]. This policy aims to promote the implementation of GRB which one of its aims is to reduce gender inequalities at the level of beneficiary development. In fact, several constraints in GRB implementation in Indonesia are generally caused by a lack of understanding of stakeholders related to GRB, lack of socialization regarding GRB implementation, and cultural challenges to gender issues in Indonesia [21].

\section{Conclusions}

The earmarking tax policy on cigarette taxes has not paid attention to gender aspects as well in terms of policy formulation and implementation. It might be reasonable since the tax issues in Indonesia has not been widely associated with gender issues. However, cigarette consumption dominated by men tends to have a negative impact on children and women as secondhand smokers. This gender issue has not been discussed in the tax policy on tobacco consumption in Indonesia. Therefore, it is essential to build a framework of study regarding new policies on sensitive-gender tobacco control, particularly GRB, specifically concerned with the allocation of tax revenues for empowering women. 
Acknowledgments. This study is a part of the output of International Indexed Publications for Students' Final Project of Universitas Indonesia (PITTA UI) Grant of 2018 funded by the Directorate of Research and Community Service of Universitas Indonesia.

\section{References}

[1] G. G. H. Amul and T. P. Pang, "The State of Tobacco Control in ASEAN: Framing the Implementation of the FCTC from a Health Systems Perspective," Asia Pacific Policy Stud., vol. 5, no. 1 , pp. 47-64, Jan. 2018.

[2] World Health Organization, "Monitor tobacco use and prevention policies."

[3] The Government of the Republic of Indonesia, The Regulation of the Ministry of Health No. 53/2017 on the Amandement to the Regulation of the Ministry of Health No. 40/2016 on Guidelines on the Utilization of Smoking Taxes to Fund Public Health Services. 2017.

[4] The Government of the Republic of Indonesia, "Law No. 28/2009 on Regional Tax and Regional Retribution,” 2009.

[5] J. M. Buchanan, "The Economics of Earmarked Taxes," Econ. Earmarked Taxes, vol. 71, no. 5, pp. 457-469, 1963.

[6] J. M. Samet and S.-Y. Yoon, "Gender, Women, and the Tobacco Epidemic," Manila, 2010.

[7] The Ministry of Health of the Republic of Indonesia, "Basic Health Research (Riskesdas) 2013," Jakarta, 2013

[8] The Ministry of Health of the Republic of Indonesia, "Smoking behavior of Indonesian people based on Riskesdas 2007 and 2013," Jakarta, 2015.

[9] Y. Prastowo, Analysis of Indonesian Taxation Policy for Women from the Critical Theory Perspective, Second. Jakarta: PT Cita Riset Fiskal, 2018.

[10] The Provincial Government of West Java, The Regulation of West Java Province No. 12/2008. 2008.

[11] The Government of the Republic of Indonesia, The Decree of the Director General of Fiscal Balance No. 72/PK/2015 on the Proportion and Estimation of Cigarette Tax Revenue for Each Province of 2016 Fiscal Year. Indonesia, 2015.

[12] The Government of the Republic of Indonesia, The Decree of the Director General of Fiscal Balance No. 37/PK/2016 on the Proportion and Estimation of Cigarette Tax Revenue for Each Province of 2017 Fiscal Year. 2016.

[13] The Government of the Republic of Indonesia, The Decree of the Director General of Fiscal Balance No.53/PK/2017 on the Proportion and Estimation of Cigarette Tax Revenue for Each Province of 2018 Fiscal Year. 2017.

[14] E. A. Purwanto and D. R. Sulistyastuti, Implementation of public policy: Concepts and application in Indonesia. Yogyakarta: Gava Media, 2012.

[15] W. McCleary, "The earmarking of government revenue: A review of some world bank experience," World Bank Res. Obs., vol. 6, no. 1, pp. 81-104, 1991.

[16] R. M. Bird and J. Jun, "Earmarking in theory and Korean practice," ITP Pap., vol. 513, 2005.

[17] I. Inayati, "Earmarking tax policy on local taxes in Indonesia: Toward pro fiscal legitimacy and budget flexibility policy," Universitas Indonesia, 2016.

[18] M.-A. Stephenson, "A Guide to Gender-Responsive Budgeting What is gender-responsive budgeting?"

[19] The Ministry of Foreign Affairs Foreign Information \& Communication of the Netherlands, "Economics and Finance: Budget Impact Assessments (Gender Budgeting)," The Hague, 2002.

[20] The Ministry of Finance and the the Ministry of Women's Empowerment and Child Protection of the Republic Indonesia, "Guide to gender responsive planning and budgeting within the Ministry of Finance of Republic of Indonesia," Jakarta, 2010.

[21] N. Khaerah and D. Mutiarin, "Gender responsive budgeting integration in regional expenditures budget (study on budget of Makassar city health office year 2014)," J. Ilmu Pemerintah. dan Kebijak. Publik, vol. 3, no. 3, pp. 413-445, 2017. 